\title{
Some results of comparison between the lower thermosphere zonal winds as seen by the ground-based radars and WINDII on UARS
}

\author{
Yu. I. Portnyagin ${ }^{1}$, T. V. Solovjova ${ }^{1}$, and D. Y. Wang ${ }^{2}$ \\ ${ }^{1}$ Institute for Experimental Meteorology, Obninsk, Russia \\ ${ }^{2}$ Centre for Research in Earth and Space Technology, Ontario, Canada
}

(Received July 14, 1998; Revised February 8, 1999; Accepted February 8, 1999)

\begin{abstract}
The seasonal variations of the zonal winds measured by meteor/MF radars and by the wind-imaging interferometer (WINDII) on board of the UARS satellite, are analyzed and compared with the ground-based Global Empirical Wind Model (GEWM) and satellite-based WINDII prevailing wind model, which are independently derived from the observational data sets. A general consistency in the main global scale wind structures is observed. The seasonal variations of zonal wind in the both models are described by almost the same annual and semi-annual components. But systematic bias is found for the annual mean zonal winds of the two models, with the GEWM winds generally smaller than those of WINDII by factor 2-2.5. This bias is practically independent of altitude and can be described by a term of $A \cos 4 x$, where $A$ is about $20 \mathrm{~m} / \mathrm{s}$ and $x$ is colatitude. Possible origin of this offset is discussed.
\end{abstract}

\section{Introduction}

Various global empirical wind models play an important role in our understanding of main regularities in the upper mesosphere/lower thermosphere dynamics. Among others, the models derived from the ground-based radar wind measurements have been published by Portnyagin $(1984,1987)$, Portnyagin and Solovjova (1992). Constant accumulation of data sets collected from ground- and space-based instruments has continuously stimulated the development and improvement of these models. The updated version of the models (hereafter called as GEWM) is based on the most recently available ground-based meteor radar and MF (partial reflection) wind measurements. Meanwhile, direct wind observations from UARS experiment provide unique global data sets with a substantial increase in the quantity of available wind measurements in the mesosphere and lower thermosphere. Based on the WINDII green line wind data, Wang et al. (1997) have proposed an empirical horizontal wind model. Here we present the results of comparison between zonal winds retrieved from the GEWM and the WINDII model to show their general consistency and significant difference.

\section{Global Empirical Wind Model}

The discussed GEWM is constructed by assimilating the all available data from meteor radar and MF wind measurements in the upper mesosphere/lower thermosphere. The measurement's sites and the observational periods are presented in Table 1. The meteor radar wind data (including those obtained for the average height of about $95 \mathrm{~km}$ ) are seen to give us the bulk ground-based information about the wind regime in the lower thermosphere.

Copy right (C) The Society of Geomagnetism and Earth, Planetary and Space Sciences (SGEPSS); The Seismological Society of Japan; The Volcanological Society of Japan; The Geodetic Society of Japan; The Japanese Society for Planetary Sciences.
The first step in construction of the model is to interpolate (and somewhere extrapolate) the all height-resolved experimental monthly mean wind values (height profiles) to constant height levels with a standard step (usually $1 \mathrm{~km}$ ). Then the wind values at each height level were interpolated over latitude using a routine cubic spline procedure. The obtained values were additionally smoothed over latitude with help of the Legendre function's decomposition. This procedure is correct for the zonal mean wind models. (Actually, the zero winds at the poles are assumed.)

The next step is adaptation of the above-derived preliminary model to the meteor wind data without height resolution. These data are usually related to an average height of about 95 $\mathrm{km}$ at different latitudes, and show very consistent and regular seasonal behaviour, practically the same as that deduced from the meteor radar wind measurements with height resolution. We have estimated the effect of averaging over height on the monthly mean winds by using the measurements of the Kazan meteor radar with height resolution Lysenko et al. (1994). The general conclusion is that the seasonal course of the height-averaged and height-resolved monthly mean meteor wind data are well matched at the particular height of about $95 \mathrm{~km}$, and that climatic features for their seasonal variations are very persistent, independent of longitude and observational periods and consistent for all types of devices. This conclusion is supported by comparison of the wind data measured at other latitudinal belts with and without height resolution (see Table 1).

Based on these results, we tuned the preliminary wind profiles at about $95 \mathrm{~km}$ to include the height-averaged data observed at the particular sites. Then, the smoothing procedure over latitude, as described at the first step, were repeated for the whole set of the wind profiles. In the two steps of constructing the model, the statistical weight (in a climatological sense) of the measurement data was also taken into account. 
Table 1. Data base.

\begin{tabular}{|c|c|c|c|c|}
\hline Station & Location & Method & Observing period & References \\
\hline Heiss I. & $80.5^{\circ} \mathrm{N}, 58^{\circ} \mathrm{E}$ & $\mathrm{MR}^{*}$ & $1.1965-10.1985$ & Portnyagin (1986) \\
\hline Tromso & $70^{\circ} \mathrm{N}, 19^{\circ} \mathrm{E}$ & MF & 1987-1989 & Manson et al. (1991) \\
\hline Kiruna** & $68^{\circ} \mathrm{N}, 20^{\circ} \mathrm{E}$ & $\mathrm{MR}^{*}$ & $1974-1975$ & Manson et al. (1985) \\
\hline Poker Flat & $65^{\circ} \mathrm{N}, 147^{\circ} \mathrm{W}$ & MR & $7.1980-12.1984$ & Manson et al. (1987) \\
\hline College & $65^{\circ} \mathrm{N}, 148^{\circ} \mathrm{W}$ & $\mathrm{MR}^{*}$ & $1.1967-8.1968$ & Hook (1970) \\
\hline Tomsk & $57^{\circ} \mathrm{N}, 85^{\circ} \mathrm{E}$ & $\mathrm{MR}^{*}$ & $10.1965-12.1966$ & Nazarenko (1968) \\
\hline Kazan & $56^{\circ} \mathrm{N}, 49^{\circ} \mathrm{E}$ & MR & $1986-1988$ & $\begin{array}{l}\text { Fakchrutdinova (1991), } \\
\text { Sidorov et al. (1988) }\end{array}$ \\
\hline Obninsk & $55^{\circ} \mathrm{N}, 37^{\circ} \mathrm{E}$ & $\mathrm{MR}^{*}$ & 1964-1995 & Portnyagin (1986) \\
\hline Kuhlungsborn & $54^{\circ} \mathrm{N}, 12^{\circ} \mathrm{E}$ & $\mathrm{MR}^{*}$ & $\begin{array}{c}1977-1980 \\
1-3.1990\end{array}$ & $\begin{array}{l}\text { HHI Geophys. Data, 1977-1980 } \\
\text { Singer et al. (1994) }\end{array}$ \\
\hline Juliusruh & $54.6^{\circ} \mathrm{N}, 13.5^{\circ} \mathrm{E}$ & MF & 1990-1991 & Schminder et al. (1994) \\
\hline Jodrell Bank & $53^{\circ} \mathrm{N}, 2^{\circ} \mathrm{W}$ & $\mathrm{MR}^{*}$ & $1953-1958$ & Greenhow and Neufeld (1961) \\
\hline Saskatoon & $52^{\circ} \mathrm{N}, 107^{\circ} \mathrm{W}$ & MF & 1979-1982 & Manson et al. (1985) \\
\hline Sheffield & $53.3^{\circ} \mathrm{N}, 3.8^{\circ} \mathrm{W}$ & $\mathrm{MR}^{*}$ & $1-3.1990$ & Singer et al. (1994) \\
\hline Badary & $52^{\circ} \mathrm{N}, 102^{\circ} \mathrm{E}$ & $\mathrm{LF}^{*}$ & $1975-1981$ & Petruchin (1983) \\
\hline \multirow[t]{2}{*}{ Collm } & $52^{\circ} \mathrm{N}, 15^{\circ} \mathrm{E}$ & LF & $1983-1986$ & Schminder and Kurschner (1988) \\
\hline & & & $1990-1991$ & Schminder et al. (1994) \\
\hline \multirow[t]{2}{*}{ Kharkov } & $50^{\circ} \mathrm{N}, 36^{\circ} \mathrm{E}$ & $\mathrm{MR}^{*}$ & $1980-1983$ & Kalchenko (1987) \\
\hline & & MR & 1987 & Kascheev et al. (1988) \\
\hline Kiev & $50^{\circ} \mathrm{N}, 31^{\circ} \mathrm{E}$ & $\mathrm{MR}^{*}$ & $9.1964-2.1966$ & Lysenko et al. (1969) \\
\hline Khabarovsk & $49^{\circ} \mathrm{N}, 135^{\circ} \mathrm{E}$ & $\mathrm{MR}^{*}$ & $1976-1985$ & Makarov (1988) \\
\hline Volgograd & $49^{\circ} \mathrm{N}, 44^{\circ} \mathrm{E}$ & $\mathrm{MR}^{*}$ & $1978-1985$ & Portnyagin (1986) \\
\hline Garchy** & $47^{\circ} \mathrm{N}, 3^{\circ} \mathrm{E}$ & MR & $1970-1976$ & Manson et al. (1985) \\
\hline Monpazier** & $45^{\circ} \mathrm{N}, 1^{\circ} \mathrm{E}$ & MR & $1975-1980$ & Manson et al. (1985) \\
\hline Bologna & $45^{\circ} \mathrm{N}, 12^{\circ} \mathrm{E}$ & $\mathrm{MR}^{*}$ & $1-3.1990$ & Singer et al. (1994) \\
\hline Durham & $43^{\circ} \mathrm{N}, 71^{\circ} \mathrm{W}$ & MR & $1978 / 79 / 84$ & Manson et al. (1987) \\
\hline Frunze & $43^{\circ} \mathrm{N}, 73^{\circ} \mathrm{E}$ & $\mathrm{MR}^{*}$ & 1964-1982 & Karimov (1984) \\
\hline Yambol & $42.5^{\circ} \mathrm{N}, 26.5^{\circ} \mathrm{E}$ & $\mathrm{MR}^{*}$ & $2-3.1987$ & Lysenko et al. (1988) \\
\hline Urbana & $40^{\circ} \mathrm{N}, 88^{\circ} \mathrm{W}$ & MR & 1991-1992 & Franke et al. (1993) \\
\hline Dushanbe & $38^{\circ} \mathrm{N}, 68^{\circ} \mathrm{E}$ & $\mathrm{MR}^{*}$ & $1968-1969$ & Babadjanov et al. (1974) \\
\hline Ashkhabad & $37^{\circ} \mathrm{N}, 58^{\circ} \mathrm{E}$ & $\mathrm{MR}^{*}$ & $7.1988-6.1989$ & Ovezgeldyev et al. (1991) \\
\hline Kyoto & $35^{\circ} \mathrm{N}, 136^{\circ} \mathrm{E}$ & MR & $5.1983-5.1984$ & Manson et al. (1985) \\
\hline Atlanta & $34^{\circ} \mathrm{N}, 84^{\circ} \mathrm{W}$ & MR & $\begin{array}{l}1974 / 75 \\
1976 / 77\end{array}$ & Manson et al. (1985) \\
\hline Kauai & $22^{\circ} \mathrm{N}, 160^{\circ} \mathrm{W}$ & MF & $10.1990-8.1992$ & Fritts and Isler (1994) \\
\hline Punta Borinquen** & $18^{\circ} \mathrm{N}, 67^{\circ} \mathrm{W}$ & MR & $1977-1978$ & Manson et al. (1985) \\
\hline Waltair & $18^{\circ} \mathrm{N}, 83^{\circ} \mathrm{E}$ & $\mathrm{MR}^{*}$ & $7-8.1979$ & Devara et al. (1981) \\
\hline Jamaica & $18^{\circ} \mathrm{N}, 77^{\circ} \mathrm{W}$ & MR & $3.1971-2.1972$ & Scholefield and Alleyne (1975) \\
\hline Ramey & $18^{\circ} \mathrm{N}, 67^{\circ} \mathrm{W}$ & MR & $2.1981-6.1981$ & Roper (1984) \\
\hline \multirow[t]{2}{*}{ Christmas Island } & $2^{\circ} \mathrm{N}, 158^{\circ} \mathrm{W}$ & MR & $1988-1989$ & Avery et al. (1989) \\
\hline & & MF & $1.1990-6.1991$ & Vincent (1993) \\
\hline Mogadisho & $2^{\circ} \mathrm{N}, 45^{\circ} \mathrm{E}$ & $\mathrm{MR}^{*}$ & $1968-1970$ & Babadjanov et al. (1974) \\
\hline Jakarta & $6^{\circ} \mathrm{S}, 107^{\circ} \mathrm{E}$ & MR & $11.1992-10.1995$ & Tsuda (1995) \\
\hline Townsville & $20^{\circ} \mathrm{S}, 147^{\circ} \mathrm{E}$ & MF & $1978-1980$ & Manson et al. (1985) \\
\hline Grahamstone & $33.3^{\circ} \mathrm{S}, 30^{\circ} \mathrm{E}$ & MR & $1987-1993$ & Malinga and Poole (1997) \\
\hline \multirow[t]{2}{*}{ Adelaide } & $35^{\circ} \mathrm{S}, 138^{\circ} \mathrm{E}$ & MF & $1978-1983$ & Manson et al. (1985) \\
\hline & & & 1984-1986 & Manson et al. (1991) \\
\hline Christchurch & $44^{\circ} \mathrm{S}, 173^{\circ} \mathrm{E}$ & MF & $6.1978-2.1980$ & Manson et al. (1985) \\
\hline Mawson & $68^{\circ} \mathrm{S}, 63^{\circ} \mathrm{E}$ & MF & $1984-1986$ & Manson et al. (1991) \\
\hline Molodezhnaya & $68^{\circ} \mathrm{S}, 45^{\circ} \mathrm{E}$ & $\mathrm{MR}^{*}$ & $1967-1985$ & Portnyagin (1986) \\
\hline Scott Base & $78^{\circ} \mathrm{S}, 167^{\circ} \mathrm{E}$ & MF & $12.1982-11.1984$ & Portnyagin et al. (1993) \\
\hline
\end{tabular}

Notations: * - stations without height resolution; ${ }^{* *}$ - only zonal wind component. 


\section{MEAN ZONAL WIND}

\section{JANUARY}
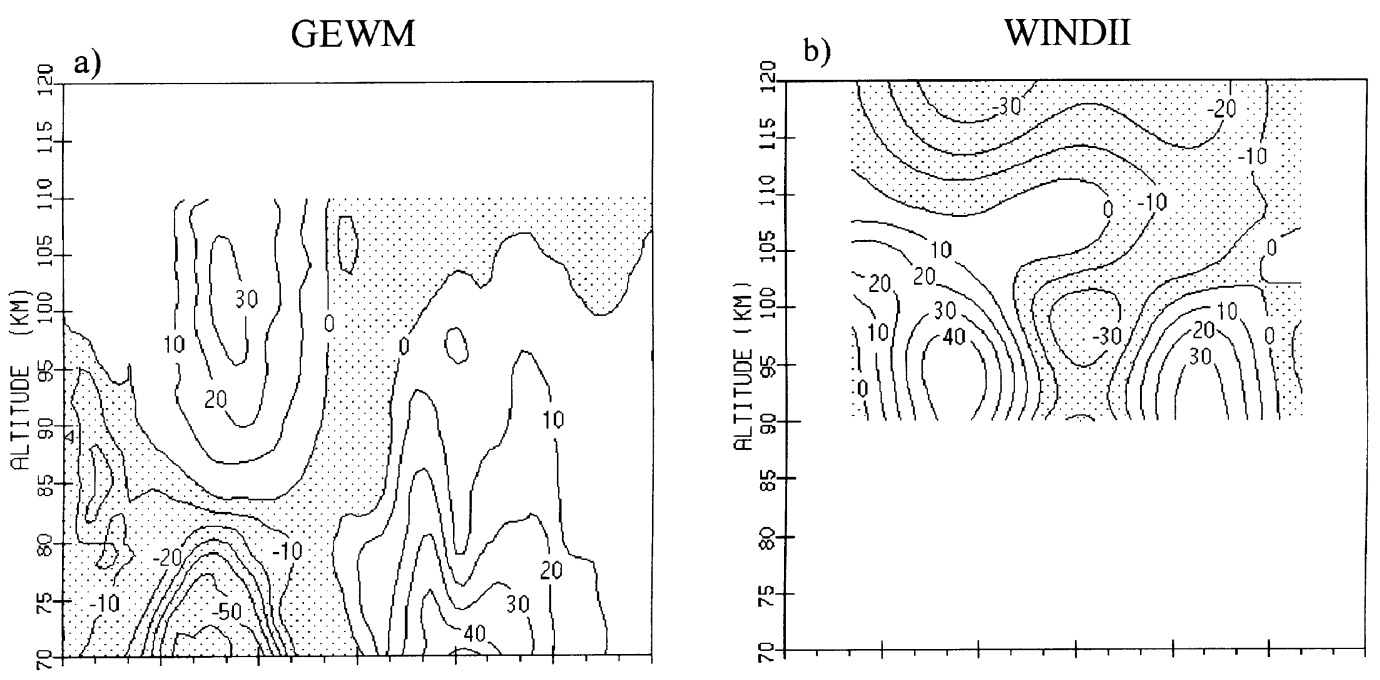

\section{JULY}
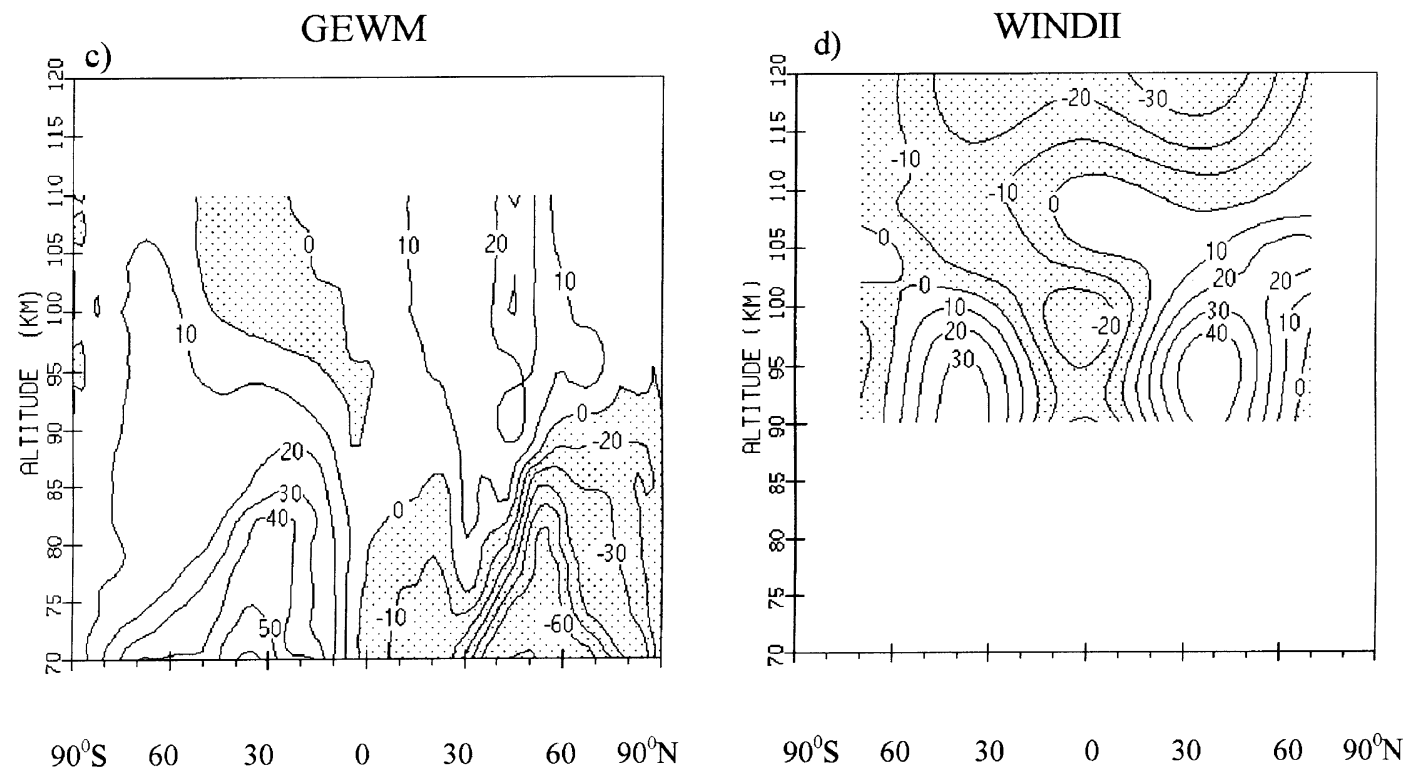

Fig. 1. Mean zonal wind for January and July. GEWM - Global Empirical Ground-Based Wind Model, WINDII - Empirical Model by Wang et al. (1997). Contour interval is $10 \mathrm{~m} / \mathrm{s}$. Westward winds are shaded.

The resulting monthly mean zonal wind values were calculated from the derived model for desirable height and latitude grids (usually, $2.5^{\circ}$ in latitude and $1 \mathrm{~km}$ in height), and the height-latitude wind isoline plots were drawn with help of a proper software.

\section{WINDII Model}

The WINDII monthly mean zonal winds used in this analysis are retrieved from the empirical horizontal wind model presented by Wang et al. (1997). The model is constructed by using the total of 324 days of wind data inferred from green line airglow emissions observed by WINDII between 90 and
$120 \mathrm{~km}$ during 1992 and 1993. The latitudinal coverage of the data alternates from $72^{\circ} \mathrm{S} / 40^{\circ} \mathrm{N}$ to $42^{\circ} \mathrm{S} / 72^{\circ} \mathrm{N}$ throughout the course of the year, determined by the WINDII viewing configuration relative to the satellite platform and the pointing direction of UARS which rotates $180^{\circ}$ with a yaw period $T_{0}=36$ days. The vertical resolution of the data is $3 \mathrm{~km}$. Over the course of a day, the satellite sampling provides about 15 longitudinal points and two different local times at a given latitude. The two local times sampled daily at each latitude remain approximately constant, changing in fact by only 20 minutes per day for successive orbits. Two successive months of the data sets can achieve a full 24 hours of 


\section{MEAN ZONAL WIND}

\section{APRIL}
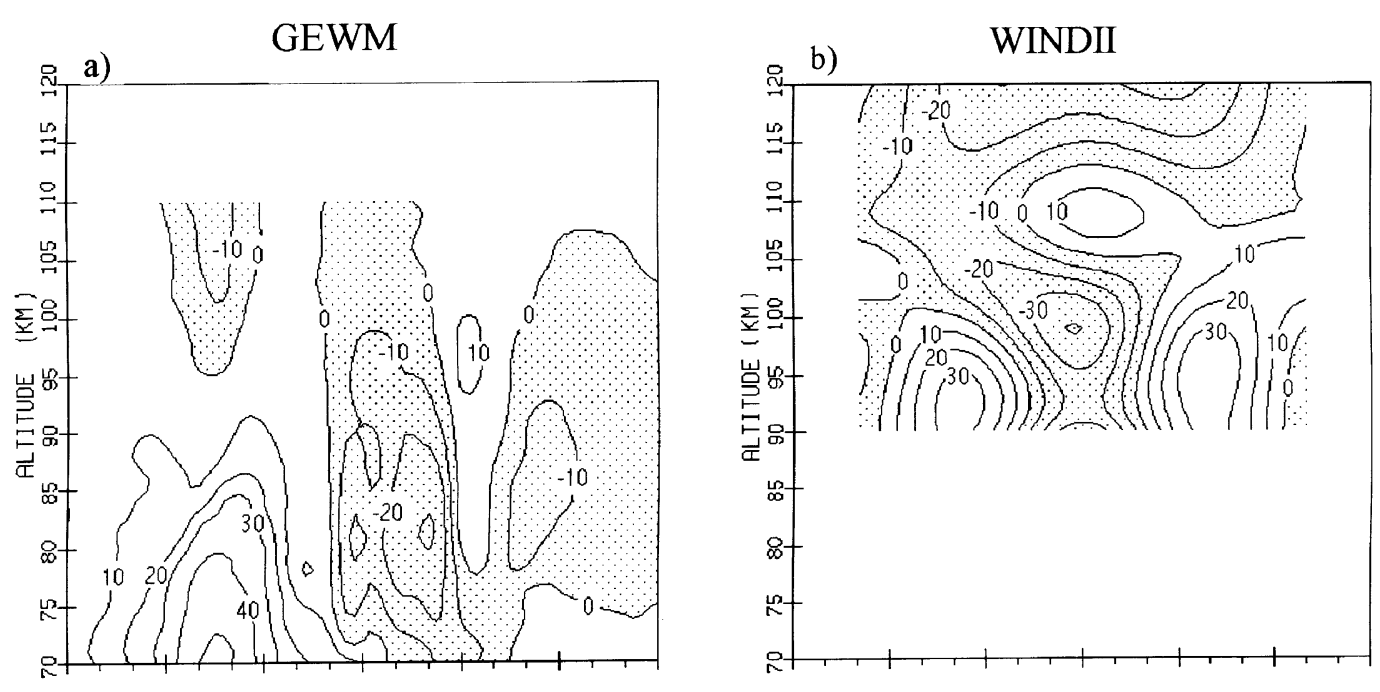

\section{OCTOBER}

c)

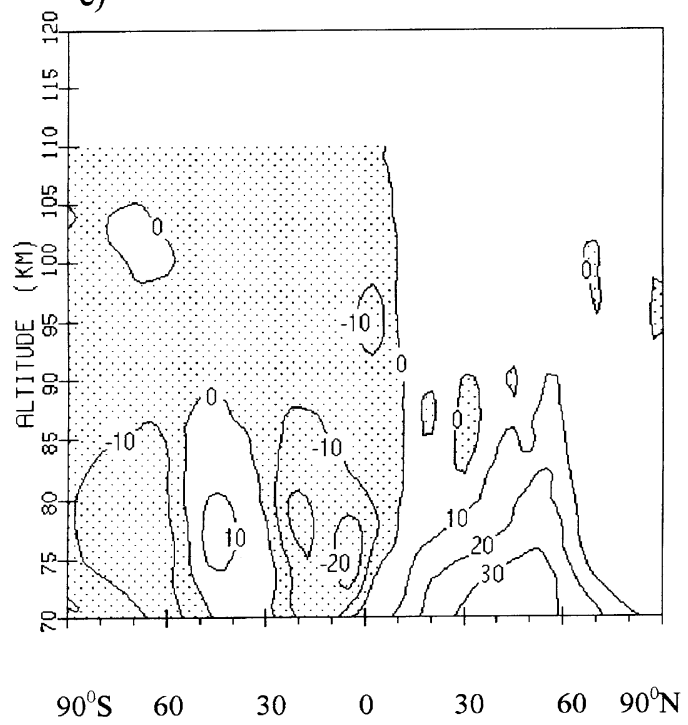

d)

WINDII

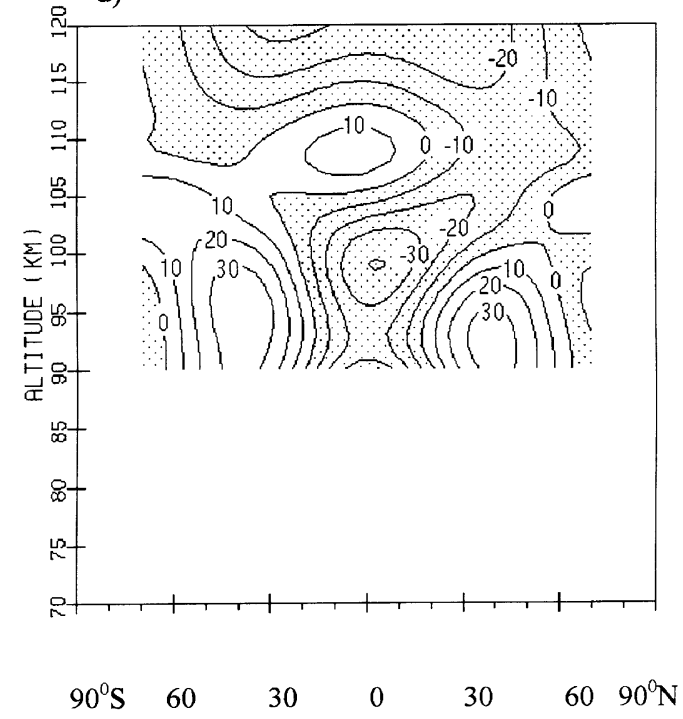

Fig. 2. Same as Fig. 1, but for April and October.

local time sampling. In accordance with the data characteristics, the vector spherical harmonic-Fourier expansion has been used to decompose the observed winds into mean winds, solar diurnal and semidiurnal tides, and stationary planetary wave components, as well as annual and semiannual variations in these fields. The model formulation is similar to that of HWM-90 and HWM-93 of Hedin et al. $(1991,1996)$, but greatly modified and extended to use the higher resolution global wind measurements now available from WINDII. With the spectral coefficients derived from the two years of WINDII wind data, the individual components of horizontal winds for an arbitrary geographic location and time at the preset height levels can be reconstructed. This decomposition greatly reduces influences of tides and stationary waves on the model-retrieved monthly mean winds. More discussion and comparison between the model and the observed data can be found in the original paper.

\section{Monthly Mean Zonal Winds of GEWM and WINDII Models}

In this section, we compare monthly mean zonal winds obtained from the GEWM and WINDII models. The results 
a)

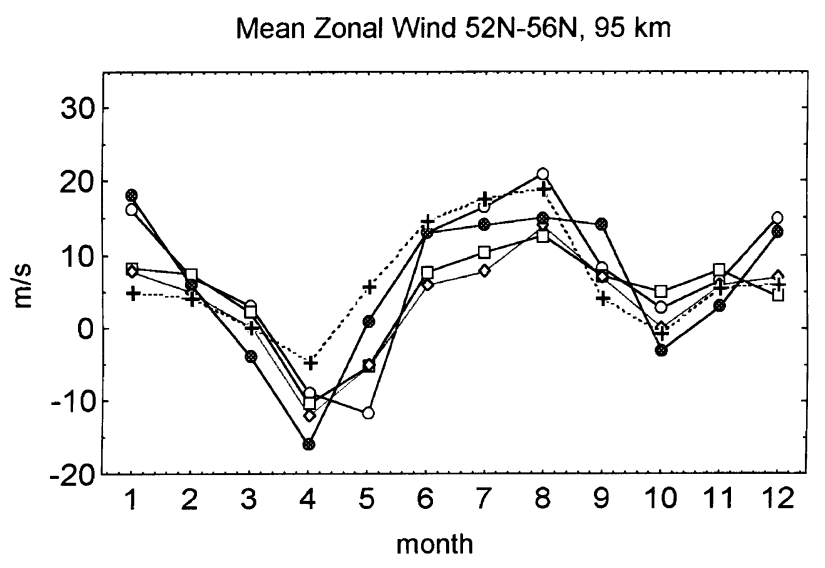

b)

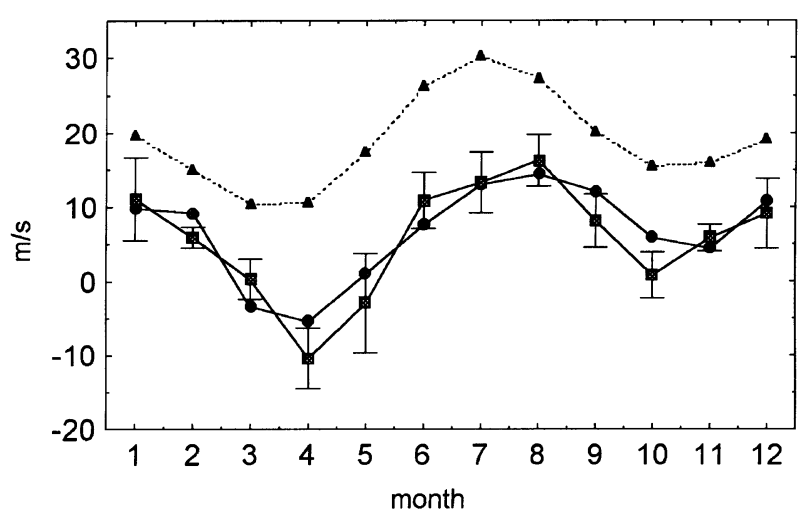

Fig. 3. Seasonal variations of mean zonal wind at $95 \mathrm{~km}$. a) $\bigcirc-$ Kazan $56^{\circ} \mathrm{N}, \square-$ Obninsk $55^{\circ} \mathrm{N}, \diamond-$ Külungsborn $54^{\circ} \mathrm{N}, \bigcirc-$ Jodrell Bank $53^{\circ} \mathrm{N}$, + - Saskatoon $52^{\circ} \mathrm{N}$; b) - GEWM $55^{\circ} \mathrm{N}$, $\mathbf{\square}$ - experimental data, $\boldsymbol{\Delta}$ WINDII $54^{\circ} \mathrm{N}$.

on the meridional component will be published in a separate paper.

The height-latitudinal cross sections of the monthly mean zonal winds are shown in Figs. 1 and 2 for the solstitial and equinoctial conditions, respectively. The altitude coverages of the two models are different. Comparison of the model results is confined to the overlapping region of 90-100 km.

In order to examine the degree of consistency and difference between the two models, Figs. 3-5 show seasonal course of the zonal winds for some latitudes at the most reliable height of about $95 \mathrm{~km}$, together with the complementary ground-based experimental data. From these figures, the seasonal courses of the GEWM and WINDII winds are seen to be very similar, but a systematic annual mean bias between the models is also evident. These observations are confirmed by Table 2, where the results of harmonic analysis for the zonal wind seasonal courses are presented. It is seen that the amplitudes and phases of the annual and semi-annual variations for two models are in good correlation. However, the significant offsets between the annual mean winds at different latitudes are also obvious.

The height-latitude structure of the offsets is shown in

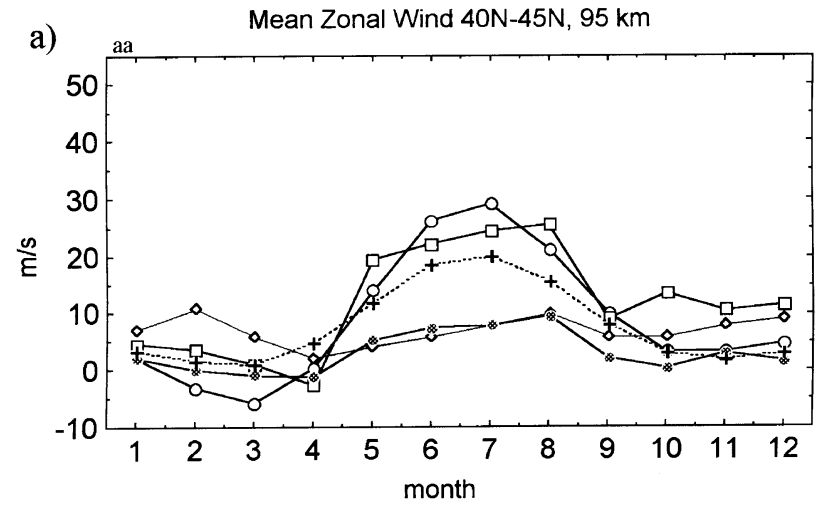

b)

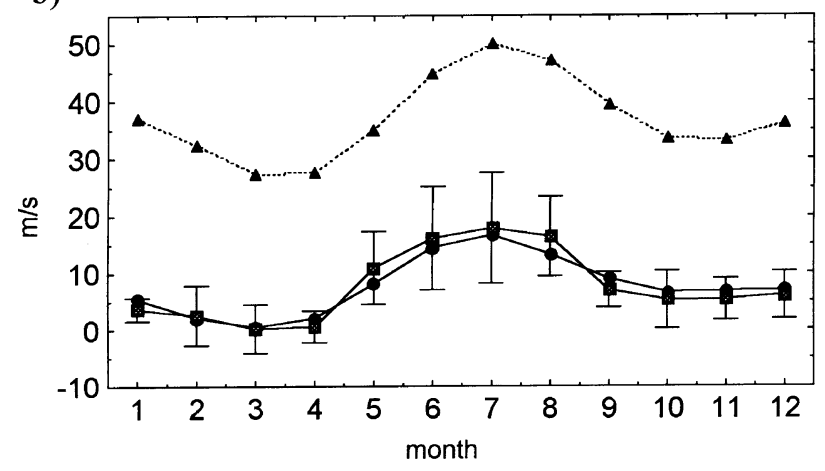

Fig. 4. Seasonal variations of mean zonal wind at $95 \mathrm{~km}$. a) $\bigcirc-$ Monpazier $45^{\circ} \mathrm{N}, \square$ - Durham $43^{\circ} \mathrm{N}, \diamond$ - Frunze $43^{\circ} \mathrm{N}$, - Jambol $42.5^{\circ} \mathrm{N},+-$ Urbana $40^{\circ} \mathrm{N}$; b) - GEWM $42.5^{\circ} \mathrm{N}, \boldsymbol{\square}$ - experimental data, $\boldsymbol{\Delta}$ - WINDII $42.5^{\circ} \mathrm{N}$.

Fig. 6a. The systematic bias between GEWM and WINDII model is seen to have a very regular latitudinal structure, which practically does not depend on height. As a result, a very good agreement between the models could be obtained, provided that the WINDII annual wind values were subtracted by a term of $A \cos 4 x$, where $x$ is colatitude and $A$ is about $20-25 \mathrm{~m} / \mathrm{s}$ and is practically independent of height. This simple function is determined from the offsets at a given height level by the least-squared fitting.

It is interesting to examine the height-latitude structure of annual mean wind itself. The annual mean zonal winds derived from GEWM (Fig. 6b) exhibit little height dependence, but show a strong latitude dependence of $A^{\prime} \cos 4 x$, where amplitude $A^{\prime}$ may be roughly considered as independent of height. The certain similarity between the Fig. $6 \mathrm{a}$ and Fig. $6 \mathrm{~b}$ is obvious. Then, our analysis shows the annual mean winds of WINDII can be expressed as $A^{\prime \prime} \cos 4 x$, where height-independent amplitude $A^{\prime \prime}=A+A^{\prime}$, and is in average equal to (2-2.5) $A^{\prime}$. Thus, the offset between the annual mean winds for the two models (cf. Figs. 6a and 6b) can be attributed to a difference by about $2-2.5$ times in the relative wind magnitude.

Due to nearly the same annual and semi-annual variations and large annual mean bias for the two models, the monthly mean winds in Figs. 1 and 2 exhibit some similarities and significant differences. For the winds in January (Fig. 1 top), 
a)

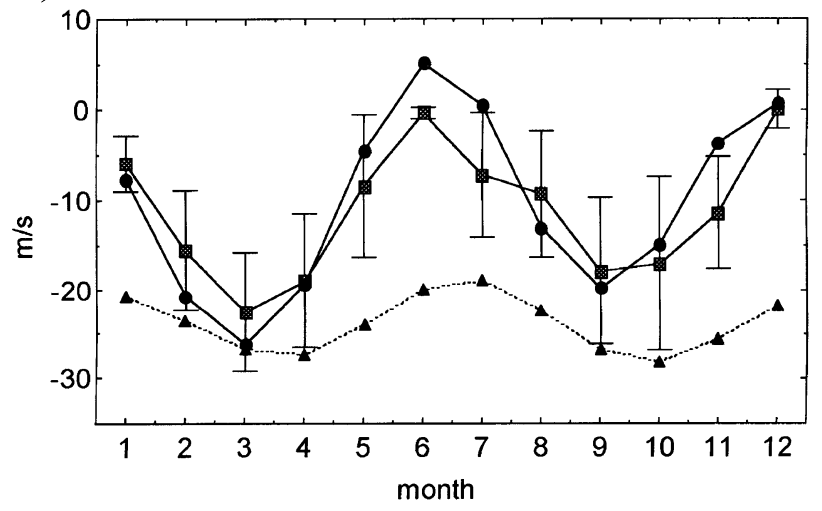

b)

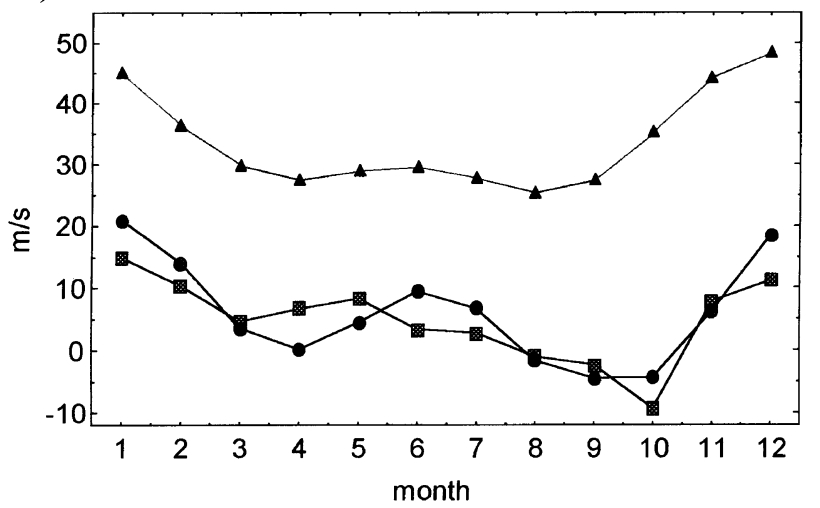

Fig. 5. Seasonal variations of mean zonal wind at $95 \mathrm{~km}$. a) - GEWM $2.5^{\circ} \mathrm{N}, \boldsymbol{\square}$ - experimental data $\left(2^{\circ} \mathrm{N}\right), \boldsymbol{\Delta}-$ WINDII $2.5^{\circ} \mathrm{N}$; b) - GEWM $45^{\circ} \mathrm{S}, \boldsymbol{\square}$ - experimental data $\left(44^{\circ} \mathrm{S}\right), \boldsymbol{\Delta}$ - WINDII $45^{\circ} \mathrm{S}$.

the most important features of the height-latitude variations are generally common for the two models.

At the mesospheric heights, the dominating structures are caused by the well-known strato-mesosphere winter cyclon and summer anticyclon vortices. In the lower thermosphere, the wind reversal with height is observed at mid-latitudes, but the height of this reversal is not the same for the two models. At lower latitudes, westward winds are observed in the whole height range. However, the exact position and the maximum wind amplitudes of these main structures are different.

The circulation patterns in July (Fig. 1, bottom) are practically the same as in January, but are reversed relative to the equator in comparison with January according to changing of seasons (winter-summer). Again the localization of the dynamical structures and the wind amplitudes are different for the different models.

For April and October (Fig. 2), the degree of similarity between the models is not too high as that for solstice months. The equinoctial GEWM winds show much weaker amplitudes in comparison with those of the space-based model.

\section{Discussion}

We have found significant systematic difference in annual mean zonal winds between the GEWM and WINDII empir-
Table 2. Zonal prevailing wind seasonal course components $95 \mathrm{~km}$.

\begin{tabular}{lrrrrr}
\hline & A0 & A1 & Ph1 & A2 & Ph2 \\
\hline $52^{\circ} \mathrm{N}-56^{\circ} \mathrm{N}$ & & & & & \\
GEWM $55^{\circ} \mathrm{N}$ & 6.6 & 5.6 & 8.9 & 6.2 & .7 \\
Mean experiment & 5.7 & 5.4 & 8.8 & 8.3 & .6 \\
WINDII $54^{\circ} \mathrm{N}$ & 18.9 & 6.0 & 7.3 & 6.0 & .4 \\
$40^{\circ} \mathrm{N}-45^{\circ} \mathrm{N}$ & & & & & \\
GEWM 42.5 $\mathrm{N}$ & 7.7 & 5.8 & 7.2 & 3.7 & .1 \\
Mean experiment & 7.7 & 7.0 & 6.8 & 4.5 & .1 \\
WINDII 42.5 $\mathrm{N}$ & 37.0 & 7.2 & 7.3 & 6.5 & .4 \\
$2^{\circ} \mathrm{N}$ & & & & & \\
GEWM $2.5^{\circ} \mathrm{N}$ & -10.2 & 4.1 & 7.4 & 13.3 & 5.5 \\
Mean experiment & -11.2 & 1.7 & 7.9 & 9.4 & 5.8 \\
WINDII 2.5 ${ }^{\circ} \mathrm{N}$ & -23.8 & 1.0 & 5.7 & 4.1 & 0.2 \\
$44^{\circ} \mathrm{S}$ & & & & & \\
GEWM 44 $\mathrm{S}$ & 6.2 & 7.1 & 1.1 & 8.7 & 0.1 \\
Mean experiment & 5.0 & 7.2 & 0.9 & 8.7 & 0.2 \\
WINDII 45 $\mathrm{S}$ & 33.8 & 9.4 & 11.7 & 5.2 & 5.5 \\
\hline
\end{tabular}

A0 - annual mean wind (m/s), A1 - amplitude of annual harmonic $(\mathrm{m} / \mathrm{s})$, $\mathrm{Ph} 1$ - phase of annual harmonic (month of maximum), A2 - amplitude of semiannual harmonic $(\mathrm{m} / \mathrm{s}), \mathrm{Ph} 2$ - phase of semiannual harmonic (month of maximum).

ical models, while the annual and semi-annual variations of zonal wind field in the two models are in good agreement, respectively. In view of the general consistency between the model representations and their own observational datasets based on which the models are constructed, the revealed discrepancy is believed to reflect the deviation between the wind measurements by the ground and space techniques.

We note that there is a lot of direct intercomparison between ground-based and space-based data. Intercalibration of HRDI and WINDII wind measurements by Burrage et al. (1997) have shown that there is no significant wind-speed bias between the two datasets. The directions are also in good agreement; the WINDII winds appear to have an offset in the zonal component of about $-6 \mathrm{~m} / \mathrm{s}$ relative to the HRDI winds, which in turn have an offset of $+2 \mathrm{~m} / \mathrm{s}$ relative to MF radars and rockets measurements, suggesting an absolute zonal wind bias of $-4 \mathrm{~m} / \mathrm{s}$ for WINDII.

The results of the most comprehensive intercomparison between simultaneous MLT winds measured by rockets, ground-based MF and meteor radars, and by space-based HRDI/WINDII were reported by Burrage et al. (1996) and Hasebe et al. (1998). Burrage et al. (1996) show that the HRDI winds agree well to those observed by radars, rockets and WINDII, except that the relative magnitude of wind speed is smaller in MF radars than in HRDI. Hasebe et al. (1997) concluded that the accuracy of HRDI winds relative to meteor radars, situated in Shigaraki and Jakarta, is found to be high, in that overall differences in the wind Shigaraki and Jakarta, is found to be high, in that overall differences in 


\section{OFFSET WINDII relative GEWM}

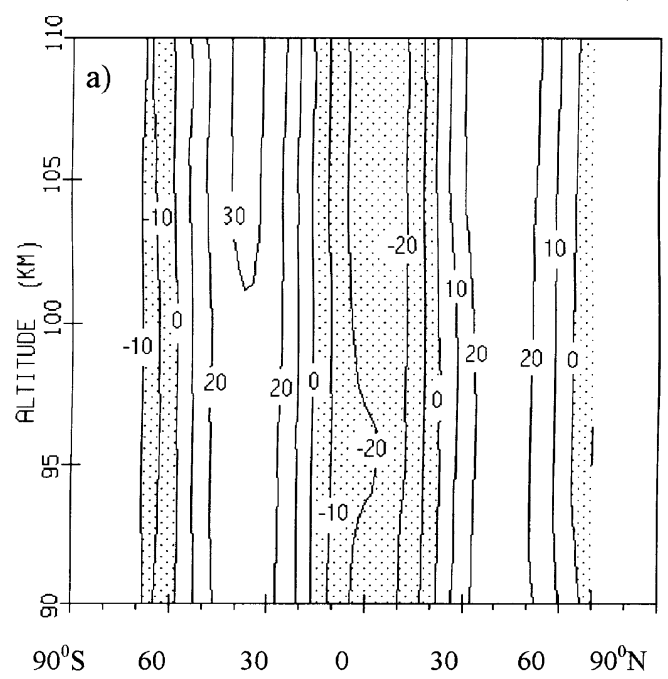

\section{GEWM Annual Mean Zonal Wind}

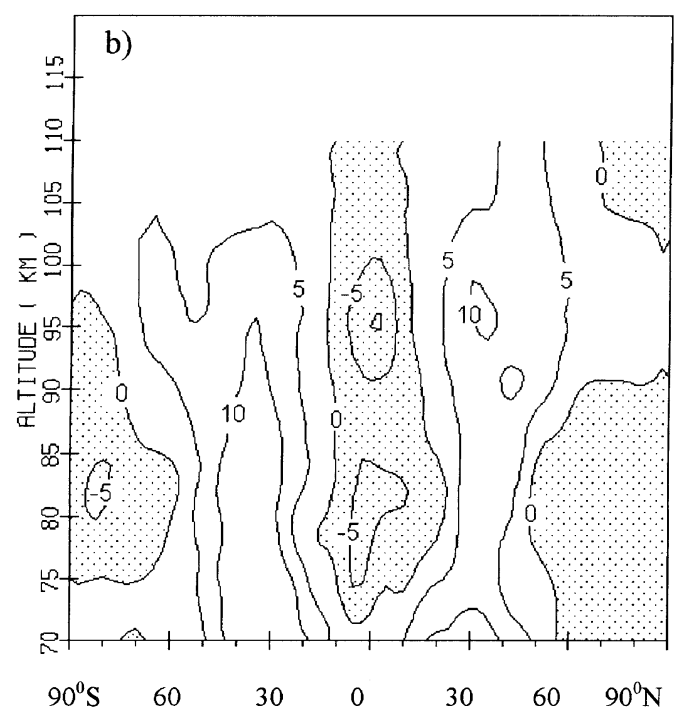

Fig. 6. a) High-latitude structure of the sistematical difference between WINDII and GEWM annual mean winds. Contour interval is $10 \mathrm{~m} / \mathrm{s}$. b) High-latitude structure of GEWM Annual Mean Wind $(\mathrm{m} / \mathrm{s})$. Contour interval is $5 \mathrm{~m} / \mathrm{s}$. Westward winds are shaded.

the wind velocities are not statistically significant at the 0.01 level between HRDI and meteor radars.

Most of the above mentioned comparisons, however, has been made for instantaneous wind profiles. In spite of the conclusions drawn from the comparison between HRDI and Jakarta meteor radar data, we note that there is a constant strong shift in the monthly mean values, while the individual wind profiles show very good correlation. This is of particular interest to our comparisons for monthly and annually mean winds.

Actually, the GEWM is mainly based on the meteor radar wind measurements, especially at about $95 \mathrm{~km}$. As shown in Section 4, significant systematic differences between the GEWM and WINDII are definitely exist. Long-term meteor and radar measurements (see Table 1) at different geographical sites have shown that the main regularities of the lower thermosphere wind regime are very persistent. For example, at $95 \mathrm{~km}$ level and at the high and mid-latitudes above $45 \mathrm{de}-$ grees in the Northern hemisphere, all meteor and MF radar wind data since the very old meteor data (1957-1961) from Jodrell Bank and up to now showed the same seasonal behavior: eastward flow for winter and summer seasons with a rather strong wind reversal in spring time and with a weaker wind, decreasing in fall. For more than 40 years of observations at different longitudes we have not found any exception from this general rule. However, the space-based WINDII empirical model and HRDI winds do not show any spring zonal wind reversal in this latitudinal belt, due to the large offset in annual mean winds.

Let us consider possible origin of the observed deviations between ground-based and satellite-based MLT winds. The ground-based radar measurements were independently taken at the different sites with the different techniques over decades of observation period. Inter-annual and longitudinal variability in the ground-based wind data may play a certain role in the observed differences. We have estimated the mean square deviations stipulated by the inter-annual and longitudinal variability. The values do not exceed $5-7 \mathrm{~m} / \mathrm{s}$ at the high and mid-latitudes (cf. Figs. 3, 4) and are about $10 \mathrm{~m} / \mathrm{s}$ at the lower latitudes (cf. Fig. 5). This deviation cannot reconcile the observed discrepancy between the annual means of the GEWM and WINDII winds. More importantly, as shown in Fig. 6a, the systematic bias remarkably regularly varies with latitude, but practically does not depend on altitude. This height-independent feature cannot be attributed to the inter-annual and longitudinal variabilities of the groundmeasured monthly means, since such variations are expected to have height distribution. In fact, if the latitudinally varying bias were eliminated in a way suggested in Section 4, a high consistency between the GEWM and WINDII winds could be achieved. This provides an indirect confirmation that the inter-annual and longitudinal effects on the bias are unimportant.

There are several factors which may be responsible for the detected bias. Vincent et al. (1994) have shown that in cases of severe MF receiver saturation the observed wind velocities would be systematically smaller that the actual wind velocities. Meek et al. (1997) have pointed out that some speed-ratio bias in the sense MFR $<$ HRDI is expected on statistical grounds. These discussions may explain the difference between MF radar and HRDI/WINDII data. However, most of GEWM data are taken by meteor radars, which are believed to be reliable at least at the most significant height of about $95 \mathrm{~km}$.

Palo et al. (1997) discussed a possibility that a possible reason for the bias between ground-based and satellite-based data may be connected with a long-period intraseasonal oscillations which would be suppressed in the UARS climatology Other possible origins may be attributed to the systematic errors in the absolute wind measurements by the satellitebased optical techniques. The WINDII winds are derived from airglow observations. In the inversion calculations, the airglow intensity error of 5\% may result in the wind error of $20 \mathrm{~m} / \mathrm{s}$. This is likely a candidate (Y. J. Rochon, private 
communication, 1998), though the exact nature is to be investigated.

For HRDI, one possible origin is the systematic errors in the absolute calibration of the line shift to Doppler velocity factor on board of UARS. As pointed out by Burrage et al. (1996), if this factor were substantially in error, the correction to account for the Earth rotation effect would lead to large errors in the measured winds, due to the maximum Earth rotation velocity of $463 \mathrm{~m} / \mathrm{s}$ at the equator in zonal direction, larger than typical MLT winds by an order of magnitude. Since the correction depends on viewing direction and latitude, the wind errors would vary with latitude, but be independent of height, suggesting the same behavior as that observed in our analysis. An additional evidence can be found in figure 24 of the above-referred paper, where an example shows the relationship between the Earth rotation contribution and the total velocity HRDI measurements for the different azimuths. The average slope of the relationship is very close to 1 (for many days of HRDI data, this slope is nearly always in the range 0.95 to 1.05 ). As pointed out by the authors, if the line shift to wind factor was in error, then this slope would not be 1 . Actually, this slope significantly deviates from the average $y=x$ line in the different latitudinal belts. The deviations have a wavelike structure relative to the latitude, similar to those of the above-discussed bias. Therefore an uncertainty in the correction to account for the rotation of the Earth may cause the observed differences between ground-based and space-based MLT wind models.

\section{Conclusions}

The GEWM and WINDII empirical wind models are constructed from the meteor/MF radars and WINDII green line airglow measurements, respectively. Comparison between the zonal winds retrieved from the models has revealed a general consistency, in particular, almost the same annual and semi-annual variation components in global scale wind structures.

However, systematic bias exists in the annual mean zonal winds. The significant offsets result in eastward flow throughout the year at $95 \mathrm{~km}$ at the high and mid-latitudes in the Northern hemisphere, inconsistent with the well-known from ground-based measurements zonal wind reversal in that region during equinoxes. The discrepancy is unlikely associated with model representation and/or inter-annual/longitudinal variabilities of the observational datasets, since similar deviations are also observed in HRDI data. Possible origin responsible for the detected bias are suggested, more investigations are required.

Acknowledgments. The authors are grateful to Drs. and Profs. G. Shepherd, M. Burrage, T. Tsuda, T. Nakamura, D. Fritts, J. Isler, R. Vincent, A. Manson, J. M. Forbes, S. Avery, G. Fraser and F. Vial for their courtesy in supplying the authors with wind measurement data in a computer readable form and for their attention to the work.

\section{References}

Avery, S. K., R. L. Obert, and J. P. Avery, Observations of equatorial mesospheric mean winds and tides, Handbook for MAP, 28, 64-67, 1989.

Babadjanov, P. B., B. L. Kascheev, V. A. Nechitailenko, and V. V. Fedynsky, Meteor Radar Study of the Upper Atmosphere Circulation, pp. 171-173, "Donisch", Dushanbe, 1974 (Book in Russian).

Burrage, M. D., W. R. Skinner, D. A. Gell, P. B. Hays, A. R. Marshall,
D. A. Ortland, A. H. Manson, S. J. Franke, D. C. Fritts, P. Hoffmann, C. McLandress, R. Niciejewsky, F. J. Schmidlin, G. G. Shepherd, D. Singer, T. Tsuda, and R. A. Vincent, Validation of mesosphere and lower thermosphere winds from the high resolution Doppler imager on UARS, J. Geophys. Res., 101, No. D6, 10,365-10,392, 1996.

Burrage, M. D., W. R. Skinner, and P. B. Hays, Intercalibration of HRDI and WINDII wind measurements, Ann. Geophys., 15, 1089-1098, 1997.

Devara, P. C. S., M. I. Achmed, M. S. Rao, and B. R. Rao, Neutral wind measurements over Waltair using meteor wind radar, J. Atmos. Terr. Phys., 43, 239-242, 1981.

Fakchrutdinova, A. N., Height-temporal structure of the lower thermosphere neutral winds and the effects of their interaction with ionospheric phenomena, D. Sc. Thesis, Kazan, 1991.

Franke, S. J. and D. Thorsen, Mean winds and tides in the upper middle atmosphere at Urbana $\left(40^{\circ} \mathrm{N}, 88^{\circ} \mathrm{W}\right)$ during 1991-1992, J. Geophys. Res., 98, 607-615, 1993.

Fritts, D. C. and J. R. Isler, Mean motions and tidal and two-day structure and variability in the mesosphere and lower thermosphere over Hawaii, J. Atmos. Sci., 51, 2145-2164, 1994.

Greenhow, J. S. and E. L. Neufeld, Winds in the upper atmosphere, Quart. J. Roy. Met. Soc., 87, 472-489, 1961.

Hasebe, F., T. Tsuda, T. Nakamura, and M. D. Burrage, Validation of HRDI MLT winds with meteor radars, Ann. Geophys., 15, 1142-1157, 1997.

Hedin, A. E., M. A. Biondi, R. G. Burnside, G. Hernandez, R. M. Johnson, T. L. Killeen, C. Mazaudier, J. W. Meriwether, J. E. Salah, R. J. Sica, R. W. Smith, N. W. Spencer, V. B. Wickwar, and T. S. Virdi, Revised global model of thermosphere winds using satellite and ground-based observations, J. Geophys. Res., 96, 7657-7688, 1991.

Hedin, A. E., E. L. Fleming, A. H. Manson, F. J. Schmidlin, S. K. Avery, R. R. Clark, S. J. Franke, G. J. Fraser, T. Tsuda, F. Vial, and R. A. Vincent Empirical wind model for the middle and lower atmosphere, J. Atmos Terr. Phys., 58, 1421-1447, 1996.

HHI Geophys. Data, Meteor Winds Suppl., DDR, Berlin, 28, 1-23, 1977. HHI Geophys. Data, Meteor Winds Suppl., DDR, Berlin, 29, 1-23, 1978. HHI Geophys. Data, Meteor Winds Suppl., DDR, Berlin, 30, 1-23, 1979. HHI Geophys. Data, Meteor Winds Suppl., DDR, Berlin, 31, 1-23, 1980.

Hook, J. L., Winds at the 75-105 km level at College, Alaska, Planet. Space Sci., 18, 1623-1638, 1970.

Kalchenko, B. V., Variations of prevailing, diurnal and semidiurnal components of wind velocity at 80-105 km heights, Meteor Researches, No. 13, Moscow, 34-42, 1987 (Russian Journal).

Karimov, K. A., Dynamical Characteristics of the Lower Thermosphere and Their Coupling with the Mesosphere/stratosphere Processes over Middle Asia Region, pp. 9-12, "Ilim", Frunze, 1984 (Book in Russian).

Kascheev, B. L., V. A. Nechitailenko, A. N. Oleinikov, and V. A. Shevchuk, Long-term variability of the vertical profiles of wind velocities in 80 $100 \mathrm{~km}$ height region, in Global Meteor Observation System, Results of Observations, pp. 5-15, Soviet Geophys. Com., Moscow, 1988 (in Russian).

Lysenko, I. A., B. L. Kascheev, M. K. Nazarenko, R. P. Chebotarev, A. D. Orlyansky, and E. I. Fialko, The results of investigations of atmosphere circulation over Euroasia and Arctic by meteor radar method, Proc. Acad. Sci. USSR, Ser. Phys. Atmos. and Ocean, 5, 893-902, 1969.

Lysenko, I. A., P. P. Michailik, B. I. Petrov, Ch. V. Spasov, and P. Ch. Manev, Wind measurements by meteor radar method in BPR, Bulgarian Geophys. J., 14, 34-47, 1988.

Lysenko, I. A., Yu. I. Portnyagin, A. N. Fahrutdinova, R. A. Ishmuratov, A. H. Manson, and C. E. Meek, Wind regime at $80-110 \mathrm{~km}$ at mid-latitues of the Nothern hemisphere, J. Atmos. Terr. Phys., 56, No. 1, 31-42, 1994.

Makarov, N. A., Main regularities of wind regime in the atmospheric meteor zone over Far East region from meteor radar measurement results, in Investigations of Dynamical Processes in the Upper Atmosphere, pp. 8 13, Moscow, Hydrometeoizdat, 1988.

Malinga, S. B. and L. M. G. Poole, Atmospheric tides observed at Grahamstown $\left(33.3^{\circ} \mathrm{S}, 26.5^{\circ} \mathrm{E}\right)$, J. Atmos. Sol.-Terr. Phys., 59(16), 2037-2050, 1997.

Manson, A. H., C. E. Meek, M. Massebeuf, J.-L. Fellous, W. G. Elford, R. A. Vincent, R. L. Craig, R. G. Roper, S. Avery, B. B. Balsley, G. J. Fraser, M. J. Smith, R. R. Clark, S. Kato, T. Tsuda, and A. Ebel, Mean winds of the upper middle atmosphere $(60-110 \mathrm{~km})$ : A global distribution from radar systems (MF, meteor, VHF), Handbook for MAP, 16, 239-268, 1985.

Manson, A. H., C. E. Meek, M. Massebeuf, J.-L. Fellous, W. G. Elford, R. A. Vincent, R. L. Craig, R. G. Roper, S. Avery, B. B. Balsley, G. J. Fraser, M. J. Smith, R. R. Clark, S. Kato, and T. Tsuda, Mean wind of the 
upper middle atmosphere $(70-110 \mathrm{~km})$ from the global radar network: comparison with CIRA-72, and new rocket and satellite data, Adv. Space Res., 7, 143-153, 1987.

Manson, A. H., C. E. Meek, E. Flemming, S. Chandra, R. A. Vincent, A. Phillips, S. K. Avery, G. J. Fraser, M. J. Smith, J. L. Fellous, and M. Massebeuf, Comparison between sattelite-derived gradient winds and radar-derived winds from CIRA-86, J. Atmos. Sci., 48, 411-428, 1991.

Meek, C. E., A. H. Manson, M. D. Burrage, G. Garbe, and L. L. Cogger, Comparison between Canadian prairie MF radars FPI (green and $\mathrm{OH}$ lines) and UARS HRDI systems, Ann. Geophys., 15, 1099-1110, 1997.

Nazarenko, M. K., Regular motions in the meteor zone from meteor radar observations in Tomsk in 1969, in Comets and Meteors, pp. 15-22, "Donish", Dushanbe, 1968.

Ovezgeldyev, O. G., Yu. Karadjaev, L. P. Korsunova, I. A. Lysenko, and B. I. Petrov, Some features of the lower thermosphere wind regime over Ashkhabad from meteor radar measurement data, J. Met. Hydr., N9, 5157, 1991.

Palo, S. E., M. E. Hagan, C. E. Meek, R. A. Vincent, M. D. Burrage, C. McLandress, S. J. Franke, W. E. Ward, R. R. Clark, P. Hoffmann, R. Jonson, D. Kürschner, A. H. Manson, D. Murphy, T. Nakamura, Yu. I. Portnygin, J. E. Salah, R. Schminder, W. Singer, T. Tsuda, T. S. Virdi, and Q. Zhou, An intercomparison between the GSWM, UARS, and ground based radar observations: a case-stude in January 1993, Ann. Geophys., 15, 1123-1141, 1997.

Petruchin, V. F., Lower thermosphere wind regime over East Siberia, Ph. Deg. Thesis, Irkutsk, 1983.

Portnyagin, Yu. I., Basic features of global circulation in the mesopauselower thermosphere region, Handbook for MAP, 10, 134-142, 1984.

Portnyagin, Yu. I., The climatic wind regime in the lower thermosphere from Meteor radar measurements, J. Atmos. Terr. Phys., 48, 1099-1109, 1986.

Portnyagin, Yu. I., An empirical model of the zonal circulation at the 70-110 km, Russian J. Met. Hydr., No. 4, 6-14, 1987.

Portnyagin, Yu. I. and T. V. Solovjova, An empirical model of the meridional wind in the mesopause/lower thermosphere, Part 1, a monthly mean empirical model, Russian J. Met. Hydr., No. 10, 28-35, 1992.

Portnyagin, Yu. I., J. M. Forbes, G. J. Fraser, R. A. Vincent, S. K. Avery, I. A. Lysenko, and N. A. Makarov, Dynamics of the Antarctic and Arctic mesosphere and lower thermosphere regions - I. The prevailing wind, $J$. Atmos. Terr. Phys., 55, 827-841, 1993.

Roper, R. G., Meteor wind results from Atlanta, U.S.A. and Ramey, Puerto
Rico, Handbook for MAP, 10, 127-133, 1984.

Schminder, R. and D. Kurschner, Mean winds and tides in the 85 to $110 \mathrm{~km}$ region over Central Europe in 1983-1986, J. Geophys. Res., 93, 24932497, 1988.

Schminder, R., W. Singer, D. Kurschner, P. Hoffmann, and D. Keuer, Permanent monitoring of the upper atmosphere wind field over Central Europe by a joint analysis of LF windprofiler and MF radar measurements at Collm and Juliusruh (Germany), Meteorol. Z., N.F.3, H.5, 297-300, 1994.

Scholefield, A. J. and H. Alleyne, Low latitude meteor wind observations, J. Atmos. Terr. Phys., 37, 273-286, 1975.

Sidorov, V. V., A. N. Fakchrutdinova, V. A. Makarov, R. A. Ishmuratov, and A. A. Umjarov, Height and seasonal regularities of prevailing and tidal motions from measurements in Kazan, in Global Meteor Observation System (results of observations), pp. 32-37, Soviet Geophys. Com., Moscow, 1988.

Singer, W. P. Hoffmann, A. H. Manson, C. E. Meek, R. Schminder, D. Kurschner, G. A. Kokin, A. K. Knyazev, Yu. I. Portnyagin, N. A. Makarov, A. N. Fakhrutdinova, V. V. Sidorov, G. Cevolani, H. G. Muller, E. S. Kasimirovsky, V. A. Gaidukov, R. R. Clark, R. P. Chebotarev, and Y. Karadjaev, The wind regime of the mesosphere and lower thermosphere during the DYANA campaign - I. Prevailing winds, J. Atmos. Terr. Phys., 56, 1717-1729, 1994.

Tsuda, T., A preliminary report on observations of equatorial atmosphere dynamics in Indonesia with radar and radiosondes, J. Meteor. Soc. Japan, 73, 393-406, 1995.

Vincent, R. A., Long-period motions in the equatorial mesosphere, J. Atmos. Terr. Phys., 55, 1067-1080, 1993.

Vincent, R. A., D. A. Holsworth, I. M. Reid, and M. A. Cervera, Spaceantenna wind measurements: the effects of signal saturation, in Proceeding of the CNES-HQ Workshop on Wind Observations in the Middle Atmosphere, pp. 297-300, Cent. Nat. d'Etud. Spatiales, Paris, 1994.

Wang, D. Y., C. McLandress, E. L. Fleming, W. E. Ward, B. Solheim, and G. G. Shepherd, Empirical model of 90-120 km horizontal winds from wind-imaging interferometer green line measurements in 1992-1993, J. Geophys. Res., 102, No. D6, 6729-6745, 1997.

Yu. I. Portnyagin (e-mail: yportgin@typhoon.obninsk.org), T. V. Solovjova, and D. Y. Wang 